\title{
PENGARUH TIPE KEPEMIMPINAN PADA PERSEPSI POLITIK DAN OUTCOMES ORGANISASIONAL DENGAN INGRASIASI SEBAGAI VARIABEL PEMODERASI
}

\author{
Triana Fitriastuti \\ Fakultas Ekonomi Universitas Mulawarman \\ e-mail: triana.fitriastuti@gmail.com
}

\begin{abstract}
Perception of organizational politics has important role in the organization. It's because many empirical findings show that perception of organizational politics have impact on performance. Many factors have contributed to the development of organizational politics. The purpose of this study are to investigate the impact of transformational and transactional leadership on perception of organizational politics and to investigate the impact of perception of organizational politics on organizational outcomes such as job satisfaction, affective commitment with ingratiation as moderating variable. The research finding that transformational leadership have negative impact on perception of organizational politics, transactional leadership have no impact on perception of organizational politics, perception of organizational politics have negative impact on job satisfaction, perception of organizational politics have no impact on affective commitment, ingratiation moderate the relationship beween perception of organizational politics and job satisfaction, ingratiation moderate the relationship between perception of organizational politics and affective commitment.
\end{abstract}

Keywords: perception of organizational politics, transformational, transactional, ingratiation.

\begin{abstract}
Abstrak
Persepsi politik organisasional memiliki pengaruh penting dalam organisasi. Penelitianpenelitian sebelumnya menunjukkan persepsi politik organisasional berpengaruh negatif pada kinerja. Persepsi politik organisasional bukan suatu hal yang terbentuk dengan sendirinya. Salah satu diantaranya adalah faktor situasional yaitu kepemimpinan atasan. Tujuan penelitian ini adalah menguji pengaruh kepemimpinan transformasional dan transaksional pada persepsi politik organisasional dan menguji pengaruh persepsi politik organisasional pada outcomes organisasional seperti kepuasan kerja dan komitmen afektif dengan menggunakan ingrasiasi sebagai variabel pemoderasi. Hasil penelitian menunjukkan bahwa kepemimpinan transformasional berpengaruh negatif pada persepsi politik organisasional, kepemimpinan transaksional tidak berpengaruh pada persepsi politik organisasional, persepsi politik organisasional berpengaruh negatif pada kepuasan kerja, persepsi politik organisasional tidak berpengaruh pada komitmen afektif, Ingrasiasi memoderasi pengaruh persepsi politik organisasional pada kepuasan kerja dan Ingrasiasi memoderasi pengaruh persepsi politik organisasional pada komitmen afektif.
\end{abstract}

Kata Kunci: Persepsi politik organisasional, kepemimpinan transformasional dan transaksional, ingrasiasi.

\section{PENDAHULUAN}

Studi politik organisasional tidak lepas dari studi kepemimpinan dan kekuasaan. Berhasil atau tidak kinerja organisasi dipengaruhi oleh peranan pimpinan di dalamnya. Pemimpin memiliki wewenang, otoritas dan kekuasaan sehingga mampu mengarahkan berbagai sumberdaya dalam organisasi dalam mencapai tujuannya walaupun dalam pelaksanaannya pimpinan menggunakan tipe kepemimpinan yang mungkin dapat menyebabkan timbulnya persepsi politik organisasional sehingga berpotensi mengakibatkan outcomes negatif. 
Persepsi politik organisasional memiliki pengaruh penting karena berpengaruh negatif pada kinerja dan bukan suatu hal yang terbentuk dengan sendirinya. Ada unsur-unsur pembentuk persepsi politik organisasional yang berasal dari dalam dan dari luar diri seseorang. Salah satu faktor dari luar (faktor situasional) yang mempengaruhi persepsi politik organisasional adalah kepemimpinan atasan (Ferris et al., 1989; Ferris and Kacmar, 1992; Valle and Perrewe, 2000; Vigoda, 2007). Penelitian ini memilih kepemimpinan atasan sebagai anteseden persepsi politik organisasional berdasarkan pada argumen bahwa persepsi politik organisasional perlu diminimalisasi, bahkan dihindari, karena persepsi politik organisasional mempengaruhi kinerja bawahan (Ferris and Kacmar 1992; Cropanzano et al., 1997; Randal et al., 1999; Kacmar and Baron 1999; Valle and Perrewe 2000; Witt et al., 2000; Witt et al., 2002). Tugas atasan adalah meminimalisasi timbulnya persepsi politik organisasional, karena atasan berkepentingan dengan pencapaian sasaran kinerja organisasi, yang akan tercapai jika setiap karyawan berkinerja dengan baik.

Ferris et al. (1989) menyatakan bahwa pimpinan atau supervisor merupakan salah satu prediktor dalam terciptanya persepsi politik dalam organisasi. Hal ini sejalan dengan penelitian yang dilakukan oleh Ferris and Kacmar (1992), Kacmar and Baron (1999), Valle and Perrewe (2000). Namun tidak dapat diketahui dengan pasti, atasan dengan tipe kepemimpinan seperti apa yang menjadi anteseden atau dapat mengurangi timbulnya persepsi politik organisasional. Jika tipe kepemimpinan tertentu sebagai anteseden persepsi politik organisasional dapat diketahui, maka persepsi politik organisasional dapat diminimalisasi dengan lebih baik, sehingga mengurangi efek negatif persepsi politik organisasional.

Politik organisasional memungkinkan untuk menghasilkan hasil kerja yang negatif berupa kepuasan kerja, komitmen organisasional, keinginan untuk keluar dan kesuksesan karir (Ferris and Kacmar 1992; Cropanzano et al. 1997; Randal et al., 1999; Kacmar and Baron 1999; Valle and Perrewe 2000; Witt et al., 2000; Witt et al., 2002). Mayoritas penelitian dalam bidang keperilakuan khususnya penelitian dalam bidang politik organisasional, telah menemukan hubungan positif secara signifikan antara kepuasan kerja dan komitmen organisasi (Cropanzano et al., 1997; Randal et al., 1999; Kacmar and Baron, 1999; Valle and Perrewe, 2000). Namun, penemuan beberapa penelitian sebelumnya yang dilakukan oleh Ferris et al. (1989), Kacmar and Baron (1999), Valle and Perrewe (2000), Cable and Judge (2003) serta Cook et al p(1999) menyatakan bahwa karyawan akan kurang terpengaruh oleh politik di tempat kerja ketika memiliki pemahaman terhadap peristiwa-peristiwa yang terjadi di tempat kerja dan merasa memiliki kendali atas peristiwa-peristiwa tersebut. Selain itu, cara lain dari anggota organisasi untuk mengurangi efek negatif perilaku politik organisasional adalah dengan terlibat langsung dalam politik itu sendiri. Tindakan berperilaku politik dapat berupa ingratiation (perilaku menjilat) dengan tujuan untuk mengurangi ambiguitas dan mencoba untuk mendapatkan kendali atas lingkungan yang tidak pasti. Karena perannya yang dapat mengurangi persepsi politik organisasional, maka dalam penelitian ini diputuskan perilaku politik adalah variabel pemoderasi yang mempengaruh persepsi politik organisasional pada kepuasan kerja dan komitmen organisasi.

Berdasarkan uraian-uraian sebelumnya, maka dapat disimpulkan isu empiris dalam studi ini didisain secara spesifik mengeksplor hubungan antara pengalaman karyawan mengenai persepsi tentang pemimpinnya dan sifat dasar hubungan antara karyawan dan pemimpin, yang dapat menciptakan persepsi politik organisasional dan pada akhirnya mengarahkan respon individual untuk menghadapi persepsi politik dengan ingrasiasi. Terkait dengan model ini, pemimpin secara langsung berhubungan dengan lingkungan politis, yang memberikan dampak secara individu maupun organisasi yang lebih besar (Carlson and Perrewe, 1995).

Selanjutnya penelitian ini berusaha untuk menjawab pertanyaan: Apakah kepemimpinan transformasional berpengaruh negatif pada persepsi politik organisasional? Apakah kepemimpinan transaksional berpengaruh positif pada persepsi politik organisasional? Apakah persepsi politik organisasional berpengaruh pada kepuasan kerja dan komitmen afektif? Apakah ingrasiasi memoderasi 
persepsi politik organisasional pada kepuasan kerja dan komitmen afektif?

\section{KAJIAN PUSTAKA}

\section{Teori Kepemimpinan}

Kepemimpinan merupakan salah satu elemen penting dalam mencapai, mempertahankan dan meningkatkan kinerja organisasi. Selain itu dimensi kepemimpinan juga merupakan salah satu anteseden dalam terbentuknya persepsi politik organisasional yang merupakan bagian dari konstruk pengaruh lingkungan kerja (Ferris et al., 1989; Ferris and Kacmar, 1992; Valle and Perrewe, 2000).

Satu fungsi dasar kepemimpinan adalah untuk menciptakan perasaan positif dan menciptakan perasaan memiliki karyawan terhadap perusahaan. Dalam penelitian ini peran kepemimpinan diwakili oleh model kepemimpinan Full Range (MLQ) yang dikembangkan oleh Bass (1985). Teori kepemimpinan transformasional, pertama kali dikemukakan oleh Bernard M. Bass, yang dibangun di atas gagasan-gagasan yang lebih dulu dikemukakan oleh Burns (1978) yang mendefinisikan kepemimpinan transformasional sebagai sebuah proses untuk mencapai tujuan kolektif, melalui penyatuan motif-motif yang saling menguntungkan yang dimiliki pemimpin dan bawahan dalam rangka mencapai perubahan yang diinginkan. Sementara Greenberg and Baron (2000) dalam Prajogo (2008) mendefinisikan kepemimpinan transformasional sebagai suatu perilaku kepemimpinan yang menggunakan kharismanya untuk mentransformasi dan merevitalisasi organisasi.

Penelitian-penelitian tentang kepemimpinan transformasional telah menghasilkan kesimpulan bahwa perilaku-perilaku pemimpin transformasional mampu membangkitkan motivasi kerja dan kepuasan kerja bawahannya. Baik motivasi kerja maupun kepuasan kerja karyawan sangat penting artinya bagi organisasi, karenanya bidang ini sangat menarik perhatian para akademisi maupun para praktisi. Pemimpin tranformasional juga diyakini mampu membangun komitmen organisasional karyawan melalui upaya-upaya untuk memberdayakan dan mentransformasi para bawahannya. Demikian juga, penelitian-penelitian tentang kepemimpinan transformasional membuktikan (Podsakoff et al., 1996) bahwa peri- laku pemimpin transformasional dapat mendorong para bawahannya untuk memerankan Organizational Citizenship Behavior (OCB).

Kepemimpinan transaksional mengacu pada adanya pertukaran peran antara pimpinan dan bawahan, para pemimpin transaksional menetapkan peran-peran dan tugas-tugas yang diperlukan para pengikutnya untuk mencapai hasil yang dikehendaki dan mengetahui apa yang sebenarnya dibutuhkan dan diinginkan oleh para pengikutnya, serta menjelaskan bagaimana kebutuhan dan keinginan tersebut akan terpenuhi jika para pengikutnya mencurahkan segala usahanya untuk pelaksanaan tugas (Avolio and Bass, 1990). Jelaslah bahwa hal ini merupakan suatu pertukaran, yaitu pemimpin meminta bawahan untuk tugas tertentu dan bawahan bersedia melaksanakan tugas tersebut demi terpenuhi kebutuhan dan keinginannya.

Menurut Avolio and Bass (1990), kepemimpinan transaksional digambarkan sebagai mempertukarkan sesuatu yang berharga bagi yang lain antara pemimpin dan bawahannya (contingent reward), intervensi yang dilakukan oleh pemimpin dalam proses organisasional dimaksudkan untuk mengendalikan dan memperbaki kesalahan yang melibatkan interaksi antara pemimpin dan bawahanya bersifat proaktif (active management by exception). Sebagai contoh, memberikan penghargaan yang tepat saat bawahanya mampu mencapai standar yang ditetapkan atau di atasnya, dan intervensi yang dilakukan oleh pemimpin dalam proses organisasional yang sebelumnya sudah ada, sepanjang cara tersebut bekerja baik dan pemimpin baru akan melakukan tindakan perbaikan bila terjadi penyimpangan (passive by management exception).

Kepemimpinan transaksional aktif menekankan pemberian penghargaan kepada bawahan untuk mencapai kinerja yang diharapkan. Oleh karena itu, secara proaktif seorang pemimpin memerlukan informasi untuk menentukan apa yang saat ini dibutuhkan bawahannya dan pemimpin harus membantu mengarahkan bawahannya pada peran dan tugas yang diperlukan untuk mencapai hasil yang diinginkannya melalui penetapan tujuan yang jelas, penjelasan keterkaitan antara kinerja dan penghargaan, serta memberikan balikan yang konstruktif untuk mempertahankan bawahan pada tugasnya (Jung and Avolio, 1999). 


\section{Persepsi Politik Organisasional dan Ingrasiasi}

Definisi persepsi politik organisasional pertama kali diperkenalkan oleh Ferris et al. (1989) sebagai perilaku yang secara strategis dirancang untuk memaksimalkan kepentingan diri walaupun kontradiktif dengan kepentingan dan tujuan organisasi dan kepentingan individu lainnya. Definisi ini diperoleh dari penelitian yang dilakukan pertama kali oleh Madison et al. (1980) yang mengamati ketika individu ditanya untuk menggambarkan politik organisasi ditempat kerja, mereka secara khusus menyusun berbagai perilaku yang dinyatakan politis yaitu memanipulasi aktivitas yang dipersepsikan tidak secara positif. Penelitian selanjutnya yang yang mengembangkan konsep ini adalah Andrews and Kacmar (2001), Cropanzano and Kacmar (1995), Drory (1993), Ferris and Kacmar (1992) yang menemukan bahwa politik ditempat kerja adalah dipersepsikan sebagai perilaku mementingkan diri sendiri untuk mencapai kepentingan diri sendiri, mengambil kesempatan, keuntungan dengan mengorbankan kepentingan yang lain dan kadang-kadang bertentangan dengan kepentingan organisasi atau unit kerja. Perilaku ini seringkali dihubungkan dengan manipulasi, fitnah, subversif dan cara yang haram dari kekuasaan untuk mencapai tujuanya.

Ferris and Kacmar (1992) melakukan penelitian tentang faktor-faktor yang mempengaruhi persepsi karyawan terhadap politik organisasional. Penelitian tersebut menghasilkan temuan bahwa politik organisasional dipengaruhi oleh tiga anteseden, yaitu 1) pengaruh organisasi, yang terdiri dari struktur organisasi sebagai bagian dari karakteristik konfigurasi disain organisasi seperti sentralisasi, formalisasi, tingkat hirarki, jangkauan pengawasan

Anteseden yang kedua adalah lingkungan kerja yang terdiri dari otonomi kerja, keragaman kerja, umpan balik, meningkatnya kesempatan, dan interaksi dengan rekan kerja dan atasan. Terciptanya politik organisasional dari anteseden ini dilihat dari seberapa besar tingkat interaksi antar sesama karyawan dan atasan, sehingga karyawan menerima informasi yang jelas tentang efektivitas kinerja mereka dari supervisor dan rekan kerja. Anteseden yang terakhir adalah pengaruh personal atau individual yaitu pengaruh alami yang ditimbul- kan oleh faktor demografis, karakteristik, kepribadian serta masalah yang berkaitan dengan nilai-nilai kemanusiaan.

Perdebatan mengenai apakah politik merupakan usaha yang buruk dengan memanfaatkan kekuasaan, kewenangan dan pengaruh dapat dilihat pula pada hasil penelitian yang tidak konsisten. penelitian yang dilakukan Cook et al. (1999), menyatakan bahwa meningkatnya perilaku politik (memperomosikan diri dan ingrasiasi) bersama dengan meningkatnya persepsi politik organisasional akan meningkatkan kepuasan kerja, baik kepuasan kerja intrinsik maupun ekstrinsik. Sebaliknya rendahnya perilaku politik akan mengakibatkan menurunnya kepuasan kerja. Selain itu, demonstrasi perilaku politik akan mengurangi efek negatif persepsi politik organisasional terhadap kepuasan kerja intrinsik dan ekstrinsik, kepuasan kerja terhadap atasan dan kesediaan untuk tetap tinggal dalam organisasi. Kontras dengan itu, rendahnya perilaku politik yang ditunjukkan dalam organisasi akan mengakibatkan rendahnya kepuasan kerja, tetapi meningkatkan kesediaan untuk tetap tinggal dalam organisasi.

Kekuasaan, pengaruh dan perilaku politis telah terjadi dimana-mana dalam organisasi formal. Konsep kekuasaan dan pengaruh dalam setting organisasi secara luas telah digantikan dengan berbagai tindakan yang memiliki arti atau istilah yang sama. Para teoris lebih lanjut telah mengajukan sejumlah kategori atas perilaku politik, yang dapat dikategorikan sebagai tipologi. Kumar and Bayerlein (1991) menyatakan bentuk perilaku politik organisasional adalah tidak mengikuti prosedur yang ada dan pantas, berada disekitar pimpinan dan melakukan lobi dengan manajer tingkat tinggi dengan maksud untuk mengambil keuntungan seperti penilaian kerja dan promosi.

Istilah ingrasiasi mengacu pada rangkaian dari taktik menyerang yang digunakan oleh anggota organisasi untuk memperoleh penerimaan yang baik dari atasan yang memiliki wewenang yang secara signifikan terkait dengan penghargaan yang diterimanya. Ingrasiasi melibatkan perilaku yang tujuannya diarahkan untuk meningkatkan ketertarikan pribadinya kepada atasan. Walaupun ingrasiasi dilakukan untuk meningkatkan kesan dimata target atau untuk meraih tujuan pribadi lainnya, perilaku ini dilakukan tanpa disadari oleh si 
target (Wortman and Linsenmeier, 1977 dalam Kumar and Beyerlein, 1999).

Ingrasiasi merupakan strategi yang kerap kali terjadi dan digunakan. Ingrasiasi yang tampak sering digunakan dalam seting organisasi memilih alasan yang sama untuk digunakan dalam latar belakang sosial secara umum untuk meningkatkan atraktifitas di mata orang yang lebih berkuasa (Jones and Wortman, 1973) dalam Kumar and Beyerlein (1991). Dengan meningkatkan ketertarikan mungkin meningkatkan kesempatan bawahan untuk dapat memberikan hasil yang positif (seperti pujian, promosi) atau mengurangi kesempatan menerima outcomes yang negatif seperti penilaian yang buruk, pemotongan gaji, pemecatan, dan lain-lain.

\section{Hubungan Antar Variabel dan Pengem- bangan Hipotesis}

Tipe kepemimpinan transformasional memiliki kemampuan dalam mengantarkan tujuan perusahaan melalui aktivitas karyawan yang lebih baik dibandingkan dengan kepemimpinan transaksional. Dimensi-dimensi kepemimpinan transformasional ini menunjukkan konsistensi hubungan yang positif dengan kinerja tugas (Fuller et al. 1996; Lowe et al. 1996).

Strategi manajerial berdasarkan tipe transformasional memberikan nilai-nilai yang kuat terhadap anggota organisasi, kemudian berkontribusi secara positif kepada anggota organisasi untuk merasakan kejujuran, keadilan kepemimpinan transformasional menciptakan sebuah iklim positif dengan melepaskan kepentingan pribadi demi kepentingan kolektif, mendorong dan membangkitkan kebutuhan bawahan, dan mengubahnya dari kepentingan sendiri ke kepentingan organisasi melakukan transparansi dalam kebijakan untuk mendukung profesionalisme. Ditambahkan, kepemimpinan transformasional juga tidak mengatasi masalah dengan mengambil jalan lain, yaitu alternatif politik. Kepemimpinan transformasional memiliki karakteristik yang dapat mengurangi persepsi dalam organisasi diantara pekerja. Hal ini sejalan dengan penelitian yang dilakukan Vigoda (2007) bahwa kepemimpinan transformasional berhubungan negatif dengan persepsi politik organisasional.
$\mathrm{H}_{1}$ : Kepemimpinan transformasional berpengaruh negatif pada persepsi politik organisasional.

Penelitian penelitian terdahulu yang membahas kepemimpinan transaksional menemukan bahwa kepemimpinan transaksional kurang efektif dibandingkan kepemimpinan transformasional (Geyer and Steyrer,1998; Lowe et al.,1996; MacKenzie et al. 2001; Parry, 2003; Pillai et al. 1999 dalam Vigoda, 2007).

Hal ini dikarenakan karakteristik yang dimiliki kepemimpinan transaksional, yaitu management by exception passive adalah perilaku atasan yang bertindak setelah masalah terjadi dapat berpengaruh negatif terhadap persepsi bawahan. Bawahan dibiarkan dalam kondisi tidak menentu, saling mencurigai, saling menuduh pihak yang paling bertanggung jawab atas kondisi yang tidak pasti dan terjadinya kesimpangsiuran informasi. Dalam kondisi ketidakpastian dan ambiguitas yang tinggi, atasan yang tidak segera mengambil tindakan akan memberikan peluang terciptanya persepsi politik organisasional. Hal ini didukung oleh penelitian Vigoda (2002) dan Vigoda (2007) yang menemukan bahwa kepemimpinan transaksional berhubungan positif dengan persepsi politik organisasional.

$\mathrm{H}_{2}$ : Kepemimpinan transaksional berpengaruh positif pada persepsi politik.

Meningkatnya persepsi politik organisasional akan berakibat negatif terhadap berbagai outcomes organisasi. Kacmar and Baron (1999) menyatakan bahwa kepuasan kerja adalah keluaran yang seringkali di uji dalam penelitian politik organisasional (Ferris and Kacmar, 1992; Cropanzano et al. 1997; Randal et al. 1999; Kacmar and Baron, 1999; Valle and Perrewe, 2000; Witt et al. 2000). Hal ini dapat dianalisis bahwa dampak merugikan yang ditimbulkan politik organisasional diperoleh dari pelanggaran kontrak sosial antara atasan dan bawahan yang sesuai dengan pertukaran sosial dan ekonomi (Keeley, 1988) dalam Randal et al. (1999). Pertukaran ini menjadi tidak seimbang bila diantara pihak yang terkait terdapat unsur ketidakadilan pada salah satu dimensi kepuasan kerja yang biasanya terjadi pada pihak yang memiliki peran lebih tinggi dalam pengambilan keputus- 
an dan politik organisasional sangat berhubungan dengan area pengambilan keputusan.

Bawahan yang mempersepsikan lingkungan kerjanya tidak sesuai harapan dan prinsip keadilan akan merasa tidak dihargai, prestasi yang telah dicapai akan sia-sia karena penilaian prestasi tidak didasarkan oleh sistem yang jujur, tetapi karena ada intrik di dalamnya yang pada gilirannya akan mempengaruhi kinerja karyawan karena kepuasan kerja diasumsikan mempengaruhi kinerja karyawan (Luthan et al. 1998). Keputusan organisasional tersebut mungkin dipersepsikan bawahan tidak mencerminkan prinsip keadilan, rasional, keprofesionalan. Dengan demikian dapat dikatakan bahwa jika pekerja mepersepsikan adanya politik dalam organisasi, maka kepuasan kerjanya akan turun, hal ini sejalan dengan beberapa penelitian sebelumnya yang telah menemukan bahwa kepuasan kerja dipengaruhi dan berhubungan negatif dengan politik organisasional (Ferris and Kacmar, 1992; Cropanzano et al., 1997; Randal et al., 1999; Kacmar and Baron, 1999; Valle and Perrewe, 2000; Witt et al., 2000).

$\mathrm{H}_{3}$ : Persepsi politik organisasional berpengaruh negatif pada kepuasan kerja.

Faktor-faktor yang mempengaruhi komitmen organisasi diantaranya adalah dukungan organisasi dan hubungan atasan bawahan. Penelitian yang dilakukan Liden et al. (1990), Wayne (1997), Klein and Kim (1998), Hutichinson and Sowa (1986), Eisenberger et al. (1990), Randall and O'driscol (1997) serta Liden et al. (1996) dalam Haryati (2006) menemukan adanya pengaruh kualitas hubungan atasan bawahan dan adanya pengaruh kuat dukungan organisasi pada komitmen organisasional. Kualitas hubungan atasan bawahan yang tercipta dengan baik akan menimbulkan kedekatan, keterlibatan bawahan dalam berbagai aktivitas atasan, dukungan, kepercayaan dan kewenangan yang diberikan atasan pada bawahan akan menumbuhkan komitmen dikalangan karyawan pada organisasinya.

Tingginya persepsi politik organisasional yang dirasakan oleh anggota organisasi akan menurunkan keterikatan perasaan bawahan terhadap organisasi karena organisasi dinyatakan tidak lagi memiliki nilai dan tujuan yang sama dengan karyawan. Bahkan perilaku politik organisasional seringkali mengabaikan norma dan nilai yang berlaku di organisasi dengan tujuan untuk mengambil keuntungan. Sehingga dapat disimpulkan, semakin tinggi persepsi politik organisasional yang dirasakan oleh bawahan maka akan menurunkan komitmen afektif (Drory, 1993; Randal et al. 1999; Cropanzano et al. 2000; Miller et al. 2008).

$\mathrm{H}_{4}$ : Persepsi politik organisasional berpengaruh negatif pada komitmen afektif.

Ketika pesepsi politik organisasional dirasakan sangat tinggi oleh karyawan, maka respon yang dilakukan bawahan untuk mengatasinya adalah dengan cara: 1) anggota organisasi menarik diri dari lingkungan; 2) mengingatkan anggota lain tetapi tidak terlibat dalam kegiatan politik; 3) bertahan dalam organisasi dan mencoba untuk terlibat dalam kegiatan politik (Cook et al. 1999). Keterlibatan karyawan dalam kegiatan politik dinyatakan sah sebagai bentuk kontrol atau sebagai mekanisme dalam menghadapi tingginya persepsi politik organisasional yang dirasakan oleh karyawan tidak menyenangkan. Selain itu, keterlibatan politik ini juga bertujuan untuk mencapai keberhasilan karier dalam pekerjaanya. Untuk mencapai keberhasilan karier dalam pekerjaanya seorang karyawan harus berorintasi proaktif yang dimanifestasikan dalam bentuk strategi karir.

Pengaruh ingrasiasi pada kesuksesan karier melalui proses psikologi sosial berdasarkan rasa suka (Ralston, 1985; Aryee et al. 1996; Wayne and Ferris, 1990; Ferris et al. 1994), yang berbentuk penilaian kinerja bawahan yang dinilai atasan mereka. Teori penilaian kinerja telah menunjukkan bahwa penilaian kerja dibuat cenderung fokus pada perasaan sang evaluator terkait dengan rangsangan obyek, yang berakibat pada akurasi penilaian kinerja. Sebagai contoh, berdasarkan penemuan studi eksperimen yang dilakukan Wayne and Ferris (1990) menemukan bahwa ingrasiasi dengan dimensi Other Enhancement (memuji orang lain) dan Rendering Favour (berbuat baik) secara positif mempengaruhi reaksi atasan terkait dengan bawahan yang menunjukkan penilaian kinerja yang baik. Hal ini terjadi karena ketika seorang atasan harus menggali informasi tentang penilaian bawahan, atasan harus membuka memori untuk membuat sebuah evaluasi dari kinerja bawahan. Proses 
menggali kembali ingatan mungkin menjadi bias karena bawahan telah memiliki karakteristik tertentu yang mewakili kinerjanya (Feldman, 1981; Ilgen and Feldman, 1983 dalam dalam Aryee et al.1996). Peran penilaian kinerja adalah sebagai tolak ukur bawahan mendapatkan penghargaan ekstrinsik dan instrinsik yang pada gilirannya bawahan merasakan kepuasan kerja karena harapan bawahan terhadap kebijakan promosi, penghargaan, upah dapat terpenuhi oleh penilaian yang dilakukan atasan.

$\mathrm{H}_{5}$ : Ingrasiasi memoderasi pengaruh persepsi politik organisasional pada kepuasan kerja.

Pada saat persepsi politik organisasional dirasakan sangat tinggi oleh bawahan, maka komitmen afektif yang dimiliki tidak lagi berdasarkan pada kontrak psikologis antara bawahan dan organisasi karena bawahan mengalami penurunan kepuasan kerja ketika promosi, penghargaan dan peningkatan kompensasi berdasarkan pada pertimbangan politik. Bawahan yang memiliki keyakinan tentang lingkungan politis dalam organisasinya akan mempengaruhi pola-pola kerja sepanjang rentang kariernya. Akhirnya pola-pola kerja bawahan akan diwarnai dengan aktivitas politik di lingkungan kerja, sesuai dengan nilai dan norma yang berlaku dalam organisasi. Sehingga keterikatan secara emosional bawahan dan organisasi berubah sesuai dengan nilai dan tujuan organisasi yaitu lingkungan organisasi yang politis.

Perubahan bentuk komitmen ini merupakan suatu bentuk mekanisme dalam menghadapi tingginya persepsi politik organisasional yang dirasakan oleh karyawan (Ferris, 1989) dan bawahan merasa organisasi sebagai pendorong perilaku politik. Vredenburgh dan Maurer (1984) mengamati perilaku anggota organisasi dibentuk oleh desain organisasi dan norma politik yang berlaku.

Selain itu penelitan yang dilakukan Kacmar and Baron (1991), Witt et al. (1998), Witt et al.. (2000) menemukan tidak konsistennya pengaruh persepsi politik organisasional pada komitmen afektif, walaupun secara teoritis sudah jelas bahwa persepsi politik organisasional pada komitmen afektif berhubungan terbalik. Randal et al. (1999), menyatakan tidak kuatnya beberapa arah hubungan persepsi politik organisasional dan komitmen organi- sasional karena sifat dasar hubungan persepsi politik dan komitmen organisasional direfleksikan dari adanya variabel pemoderasi.

$\mathrm{H}_{6}$ : Ingrasiasi memoderasi pengaruh persepsi politik organisasional pada komitmen afektif.

\section{METODE PENELITIAN}

\section{Populasi dan Sampel}

Populasi penelitian ini adalah Organisasiorganisasi yang bergerak dibidang telekomunikasi, perusahaan penambangan minyak, perguruan tinggi, perbankan, perusahaan listrik negara dan jasa konstruksi nasional dengan menggunakan metode Purposive sampling tipe judgement. Kriteria yang digunakan adalah karyawan yang pernah bekerja selama pada periode kepemimpinan tertentu minimal selama 1 tahun di organisasi yang bersangkutan dengan asumsi mereka yang telah bekerja lebih dari satu tahun sudah mengetahui pola kepemimpinan tertentu yang dirasa mampu menciptakan persepsi politik organisasional melalui kebijakan yang diambil. Sampel yang diperoleh sebanyak 240 kuesioner kembali (response rate sebesar 85,1 \%) dan 237 kuesioner yang dapat diolah (usable rate sebesar $84 \%)$.

\section{Variabel dan Indikator}

Setiap variabel akan diukur dengan item-item pertanyaan yang berbeda. Semua instrumen yang digunakan dalam penelitian ini merupakan adaptasi multi-item scale yang telah digunakan oleh beberapa penelitian sebelumnya.

Variabel transformasional diukur dengan Empat dimensi kepemimpinan transformasional yang terdiri dari 20 item yaitu Multifaktor Leadership Questionnaire versi 5X yang dikembangkan oleh Bass (1985) dalam Prajogo (2008). Empat item digunakan untuk mengukur intellectual stimulation, inspirational motivation, dan individualized consideration. Delapan item digunakan untuk mengukur idealized influence. Variabel transaksional terdiri dari Tiga dimensi pokok, yaitu contingent reward, management by exception (active) dan management by exception (passive). Ketiga dimensi ini diukur dengan 12 item The Multifaktor Leadership Questionare (MLQ) dari 
Bass and Avolio (1985). Variabel persepsi politik organisasional diukur melalui instrumen yang dikembangkan oleh Ferris and Kacmar (1991) yaitu perception of organizational politics (Perception of Organizational Politics Scale - POPS). Dimensi dari persepsi politik ini adalah 1) perilaku politik atasan yang terdiri dari kualitas hubungan atasan bawahan, 2) perilaku politik teman kerja terdiri dari 3 indikator, yaitu hubungan yang kohesif antara kelompok, jangkauan pengawasan dan formalisasi. 3) kebijakan dan praktik-praktik dalam organisasi: dimensi ini merupakan persepsi politik yang dilakukan oleh manajemen dalam praktik kebijakan organisasi, misalnya kesempatan promosi. Variabel Ingrasiasi diukur dengan menggunakan skala yang dikembangkan oleh Kacmar and Beyerlein (1991), yang direfleksikan dari perilaku meninggikan orang lain (other enhancement), menyamakan pendapat (opinion confirmity), berbuat baik (rendering favors) dan menunjukkan diri (self presentation). Total keseluruhan item dalam kuesioner ini sebanyak 15 item yang dikembangkan oleh Kacmar and Beyerlein (1991) dalam Dimensionality of the Measure of Ingratiatory Behaviors in Organizational Settings (MIBOS) Scale. Variabel kepuasan kerja diukur dengan 20 item pertanyaan yang dimodifikasi oleh Koh and Boo (2001) dengan menggunakan lima dimensi kepuasaan kerja yaitu: satisfaction with pay, satisfaction with promotion; satisfaction with co-wokers; satisfaction with supervison dan satisfaction with work. Untuk mengukur komitmen organisasi digunakan enam instrumen yang dikembangkan oleh Meyer et al. (1990), yaitu edisi revisi dari skala komitmen afektif (Meyer and Allen, 1997)

\section{Skala Pengukuran dan Pra tes}

Seluruh variable dalam penelitian ini menggunakan skala Likert-like yang artinya adalah skala Likert yang dimodifikasi. Mengacu pada instrumen yang digunakan pada penelitian sebelumnya, maka skala interval yang digunakan mulai dari skala 1 (sangat tidak setuju) sampai dengan skala 5 (sangat setuju).

Pengujian instrumen penelitian dilakukan dengan berbagai tahap seperti Pilot Study melalui pra survei dengan sampel yang lebih kecil dengan tujuan untuk mengetahui validitas instrumen yang ada dikarenakan kuesioner yang diadaptasi merupakan terjemahan bahasa asing sehingga diperlukan metode back translation alih bahasa dari Bahasa InggrisIndonesia- Bahasa Inggris.

Selain itu, pengujian instrument dilakukan melalui Pengujian validitas dan Reabilitas yang dilakukan dengan Exploratory Factor Analysis (EFA) dengan bantuan software SPSS 16.0 for windows. Konsistensi internal item-item pertanyaan dalam kuesioner akan diuji melalui pengujian Reabilitas dengan Cronbach's Alpha. Nilai yang digunakan harus lebih dari 0,7 meskipun nilai 0,6 juga masih dapat diterima (Hair et al. 2006).

\section{Jenis dan teknik pengumpulan data}

Data yang digunakan dalam penelitian ini berupa data primer dengan unit analisis individual. Data primer diperoleh dari karyawan yang dipilih sebagai sampel dengan criteria yang telah ditentukan dengan menggunakan metode survey dengan struktur pertanyaan tertutup.

\section{Teknik Analisis Data}

Metode analisis data yang digunakan dalam penelitian ini adalah metoda analisis regresi linear berganda dan Moderated Regression Analysis. Teknik ini menggunakan analisis regresi pemoderasian lewat suatu metode yang disebut dengan Moderate Regression Analysis (MRA) atau sering disebut juga Hierarchical Regression Analysis (Champoux and Peters, 1987; Baron and Kenny, 1986; Podsakoff et al. 1995; Aguinis, 1995)

\section{HASIL ANALISIS}

\section{Pengujian Instrumen}

Pengujian validitas ini dilakukan dengan Exploratory Faktor Analysis (EFA)dengan bantuan software SPSS 16.0 for windows. Nilai rule of thumb yang digunakan untuk EFA dengan loading factor harus $\geq 0.4$ (Hair et al., 2006, h.128). Sebelum melakukan analisis faktor, kriteria penting yang harus diperhatikan, yaitu hasil tes KMO dan tes Bartlett's. 
Tabel 1: Nilai KMO dan Bartlett's

\begin{tabular}{clcc}
\hline No & \multicolumn{1}{c}{ Variabel } & KMO & Bartlett's \\
\hline 1. & Variabel Independen: Kepemimpinan transformasional & 0,805 & 0,000 \\
& kepemimpinan transaksional & 0,805 & 0,000 \\
& persepsi politik organisasional & 0,828 & 0,000 \\
& ingrasiasi & 0,911 & 0,000 \\
2. & Variabel dependen (Kepuasan kerja, Komitmen afektif) & 0,792 & 0.000 \\
\hline
\end{tabular}

Data diolah: 2009

Hasil Pengujian Validitas pada dimensi Kepemimpinan Transformasional, Transaksional, persepsi politik organisasional, ingrasiasi, Kepuasan kerja dan Komitmen afektif menunjukkan masing-masing item membentuk dimensinya masing-masing.

Pada pengujian reliabilitas, semua variabel yang digunakan dalam penelitian ini memiliki nilai Cronbach Alpha di atas 0.7, sehingga semua variabel tersebut reliabel untuk dianalisis lebih lanjut, tanpa mereduksi itemitem pertanyaan yang ada.

\section{Pengujian Hipotesis}

Kepemimpinan transformasional berpengaruh negatif pada persepsi politik organisasional diterima secara signifikan dengan $\rho$-value 0,009 yang berarti hipotesis pertama didukung. Hal ini berbalik dengan hasil analisis regresi berganda yang menunjukkan bahwa kepemimpinan transaksional tidak berpengaruh pada persepsi politik organisasional yang ditunjuk- kan dengan $\rho$-value 0,615 yang berarti hipotesis kedua tidak didukung. Persamaan dua bertujuan untuk menguji pengaruh negatif persepsi politik organisasional pada kepuasan kerja dan berpengaruh negatif secara signifikan pada kepuasan kerja dengan $\rho$-value 0,009. Hasil analisis regresi berganda menunjukkan bahwa persepsi politik organisasional tidak berpengaruh pada komitmen afektif yang ditunjukkan dengan $\rho$-value sebesar 0,626.

Hasil analisis Pemoderasian menunjukkan bahwa berubahnya slope pengaruh persepsi politik organisasional yang semula negatif pada kepuasan kerja $(-0,007)$ berubah menjadi positif secara signifikan pada kepuasan kerja $(0,268)$ yang diidentifikasi pada koefisien regresi interaksi ingrasiasi ( $\beta 3)$. Hal ini sejalan dengan argumentasi Venkatraman (1990) bahwa perubahan arah moderasi (form) ini diidentifikasi pada koefisen dari persamaan regresi. Ini berarti hipotesis kelima didukung.

Tabel 2: Hasil Analisis Regresi

\begin{tabular}{llccc}
\hline \multicolumn{1}{c}{ Variabel } & Koefisien & $\boldsymbol{\tau}$-value & $\boldsymbol{\rho}$-value \\
\hline A. & Persepsi Politik Organisasional & & & \\
& Kepemimpinan Transformasional & $-0,170$ & 2,627 & 0,009 \\
& Kepemimpinan Transaksional & 0,033 & 0,504 & 0,615 \\
& Model & $\mathrm{R}^{2}=0,029$ & $\mathrm{~F}=3,487$ & 0,032 \\
B. & Kepuasan Kerja & $-0,170$ & $-2,652$ & 0,009 \\
& Persepsi Politik Organisasional & $\mathrm{R}^{2}=0,029$ & $\mathrm{~F}=7,035$ & 0,009 \\
& Model & & & \\
C. & Komitmen Afektif & $-0,032$ & $-0,488$ & 0,626 \\
& Persepsi Politik Organisasional & $\mathrm{R}^{2}=0,001$ & $\mathrm{~F}=0,239$ & 0,005 \\
\hline
\end{tabular}

* korelasi signifikan pada 0,05

Sumber: Data diolah, 2009 
Tabel 3: Hasil Analisis Regresi Moderasian

\begin{tabular}{|c|c|c|c|c|c|c|}
\hline \multirow{2}{*}{ Tahap } & \multicolumn{3}{|c|}{ Kepuasan Kerja } & \multicolumn{3}{|c|}{ Komitmen Afektif } \\
\hline & ( $\beta)$ & $\tau$ & $\rho$-value & $(\boldsymbol{\beta})$ & $\tau$ & $\rho$-value \\
\hline \multicolumn{7}{|l|}{ Tahap 1 efek utama } \\
\hline Persepsi politik & $-0,181$ & $-2,797$ & 0,006 & $-0,046$ & $-0,707$ & 0,481 \\
\hline organisasional & 0,083 & 1,282 & 0,201 & 0,114 & 1,736 & 0,084 \\
\hline Ingrasiasi & 4,349 & - & - & 1,628 & - & - \\
\hline $\mathrm{F}(\mathrm{p}<0.05)$ & 4,349 & - & - & 1,628 & - & - \\
\hline \multicolumn{7}{|l|}{ F Change $(\mathrm{p}<0.05)$} \\
\hline $\mathrm{R}^{2}$ & \multicolumn{3}{|c|}{0,036} & \multicolumn{3}{|c|}{0,014} \\
\hline$\Delta \mathrm{R}^{2}$ & \multicolumn{3}{|c|}{0,028} & \multicolumn{3}{|c|}{0,005} \\
\hline \multicolumn{7}{|l|}{ Tahap 2 interaksi: } \\
\hline Persepsi politik & $-0,007$ & $-0,082$ & 0,934 & $-0,625$ & $-12,051$ & 0,000 \\
\hline organisasional Ingrasiasi & 0,067 & 1,056 & 0,292 & 0.053 & 1,326 & 0,186 \\
\hline Interaksi & 0,268 & 3,262 & 0,001 & 1,034 & 20,095 & 0,000 \\
\hline $\mathrm{F}(\mathrm{p}<0.05)$ & 6,565 & - & - & 137,561 & - & - \\
\hline F Change $(p<0.05)$ & 6,565 & - & - & 137,561 & - & - \\
\hline $\mathrm{R}^{2}$ & \multicolumn{3}{|c|}{0,078} & \multicolumn{3}{|c|}{0,639} \\
\hline$\Delta \mathrm{R}^{2}$ & \multicolumn{3}{|c|}{0,066} & \multicolumn{3}{|c|}{0,634} \\
\hline
\end{tabular}

Sumber: Data diolah, 2009

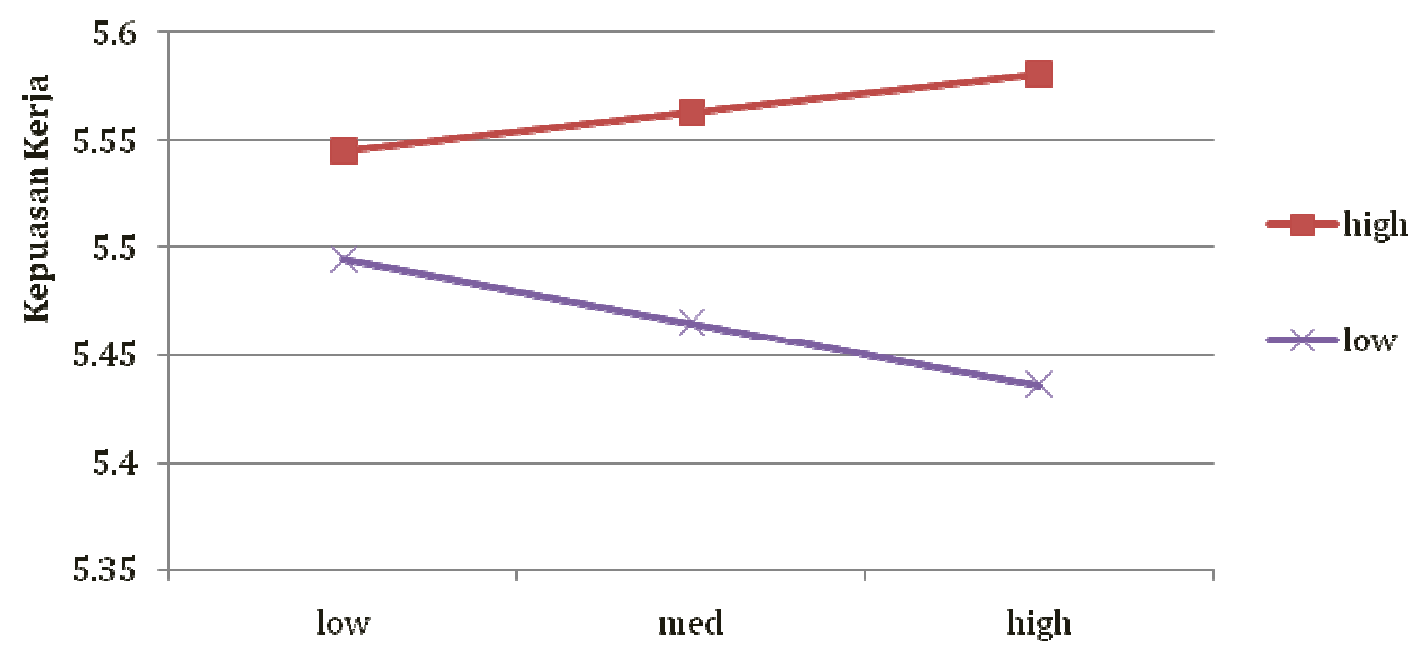

Persepsi Politik Organisasional

Gambar 1: Pengaruh Ingrasiasi Terhadap Persepsi Politik Organisasional pada Kepuasan Kerja

Efek moderasi juga dapat diidentifikasi dari perubahan nilai $\mathrm{R}^{2}$ dari $\mathrm{R}^{2}$ 0,014 menjadi $\mathrm{R}^{2}$ 0,639 dan signifikansi koefisien $\beta 3$ interaksi (variabel persepsi politik organisasional $\mathrm{x}$ variabel ingrasiasi). Interaksi antara persepsi politik organisasional berpengaruh positif secara signifikan pada variabel komitmen afektif ditunjukkan dengan $\rho$-value sebesar
0,000. Selain itu, berubahnya slope pengaruh persepsi politik organisasional yang semula negatif pada komitmen afektif $(-0,625)$ berubah menjadi positif secara signifikan pada komitmen afektif $(1,034)$ yang ditunjukkan pada koefisien regresi interaksi ingrasiasi ( $\beta 3$ ). Ini berarti hipotesis keenam didukung. 


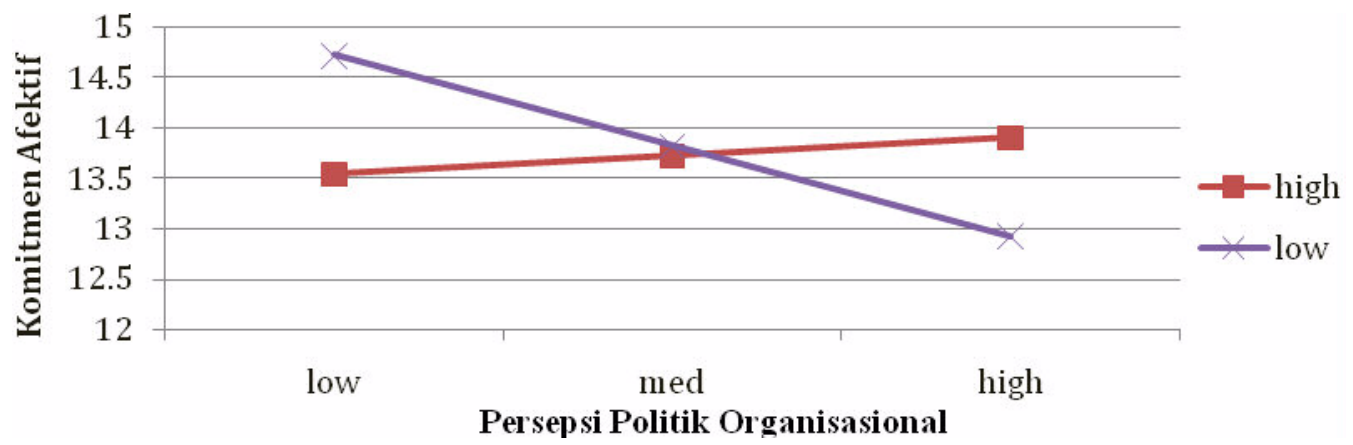

Gambar 2: Pengaruh Ingrasiasi Terhadap Persepsi Politik Organisasional pada Komitmen Afektif

\section{PEMBAHASAN}

Kepemimpinan transformasional berpengaruh negatif pada persepsi politik organisasional. Temuan ini mengindikasikan bahwa semakin sering seorang atasan berperilaku kepemimpinan transformasional, maka semakin rendah persepsi politik organisasional yang dirasakan bawahan. Hal ini dikarenakan perilaku-perilaku pemimpin transformasional seperti intelectual stimulation, inspirational motivation, individualized consideration, dan idealized influence, mampu memberikan nilai-nilai yang kuat terhadap anggota organisasi, kemudian berkontribusi secara positif kepada anggota organisasi untuk merasakan kejujuran dan keadilan dengan menciptakan sebuah iklim kerja yang positif. Kepemimpinan transformasional melepaskan kepentingan pribadi demi kepentingan kolektif, mendorong dan membangkitkan kebutuhan bawahan, dan mengubahnya dari kepentingan sendiri ke kepentingan organisasi, melakukan transparansi dalam kebijakan untuk mendukung profesionalisme.

Atasan sebaiknya lebih menekankan pada perilaku pemimpin transformasional yaitu dengan memberikan stimulasi intelektual, motivasi yang inspirasional, memperlakukan karyawan berdasarkan pertimbangan-pertimbangan individu karyawan, dan mampu mempengaruhi karyawan dengan idealisme-idealisme yang terkait dengan kesuksesan organisasi secara keseluruhan. Hal ini penting karena perilaku seorang pemimpin transformasional mampu memberikan nilai-nilai yang kuat terhadap anggota organisasi, kemudian berkontribusi secara positif kepada anggota organisasi untuk merasakan kejujuran dan keadilan dengan menciptakan sebuah iklim kerja yang positif.
Kepemimpinan transaksional tidak berpengaruh pada persepsi politik organisasional, temuan ini mengindikasikan terdapat perbedaan dengan penelitian sebelumnya yang dilakukan Vigoda (2002), Vigoda (2007) dan Ammeter et al. (2002), bahwa kepemimpinan transaksional berpengaruh secara negatif signifikan pada persepsi politik organisasional. Begitu pula dengan temuan penelitian sebelumnya bahwa kepemimpinan transaksional kurang efektif dibandingkan kepemimpinan transformasional (Geyer and Steyrer 1998; MacKenzie et al. 2001; Parry, 2003; Lowe et al. 1996; Pillai et al. 1999 dalam Vigoda, 2007).

Penjelasan alternatif temuan ini pertama, bawahan merasa tidak ada perilaku pemimpin transaksional yang dapat menjadi anteseden persepsi politik organisasional karena peran kepemimpinan transaksional dianggap sebagai fungsi manajemen yang bertugas menjelaskan standar, tawar menawar kontrak, menetapkan target dan sasaran kinerja. Kepemimpinan transaksional berperan membuat kesepakatan yang baik antara atasan bawahan, memberikan kejelasan menyangkut siapa yang yang bertanggung jawab dalam pencapaian tujuan organisasi dan melakukan koordinasi terkait keberhasilan dan kegagalan dalam pencapaian target yang diaplikasikan dalam bentuk penghargaan dan hukuman. Argumentasi ini diperkuat pernyataan Burke and Litwin (1992) bahwa kepemimpinan transaksional dianggap sebagai fungsi manajemen kepemimpinan transformasional yang dianggap sebagai fungsi seorang pemimpin. Bawahan merasa atasan yang berperilaku kepemimpinan transaksional melakukan tugas sesuai dengan prosedur operasional yang telah ditetapkan organisasi. Keberhasilan peran kepemimpinan 
transaksional akan berkontribusi pada kepemimpinan yang efektif, sehingga bawahan cenderung berasumsi bahwa kepemimpinan transaksional tidak berpengaruh pada persepsi politik organisasi.

Kedua, kepemimpinan transaksional berfungsi sebagai sebuah mekanisme dalam memahami dan mengawasi bawahan dalam lingkungan kerja mereka. Berfungsi sebagai sebuah alat yang bekerja pada saat terjadi perubahan organisasi. Perubahan menyebabkan ketidakpastian dan ambiguitas dalam organisasi yang dapat menimbulkan persepsi politik organisasional (Gandz and Murray, 1980; Ferris et al.1989; Ferris et al. 1996), sehingga dapat disimpulkan peran kepemimpinan transaksional sebagai sebuah mekanisme pengawasan, pengendalian pada saat terjadinya perubahan yang dapat mengurangi timbulnya persepsi politik organisasional. Argumentasi ini diperkuat penelitian yang dilakukan Deluga and Souza (1991) dalam studi eksperimen yang menemukan bahwa kepemimpinan transaksional tidak berhubungan dengan taktik mempengaruhi atasan yang dilakukan bawahan dan dengan menerapakan kepemimpinan transaksional akan mengurangi timbulnya taktik mempengaruhi.

Proses pengambilan keputusan yang didasari oleh ketidakadilan, hubungan dengan rekan kerja yang tidak jujur akan menimbulkan lingkungan politis karena tidak sesuai dengan standar dan harapan bawahan. Bawahan yang mempersepsikan lingkungan kerjanya tidak sesuai harapan dan prinsip keadilan akan merasa tidak dihargai, prestasi yang telah dicapai akan sia-sia karena penilaian prestasi tidak didasarkan oleh sistem yang jujur, tetapi karena ada intrik didalamnya yang pada gilirannya akan mempengaruhi kepuasan kerja. Keputusan organisasional tersebut mungkin dipersepsikan bawahan lebih bersifat politis dan tidak mencerminkan prinsip keadilan, rasional dan keprofesionalan.

Atasan perlu menyadari perilaku bawahan pada saat melakukan penilaian kinerja, karena ketika atasan harus memberikan penilaian, maka melalui proses informasi (perhatian, kategorisasi, mengingat kembali, dan mengitegrasikan informasi) atasan cenderung menilai positif, sehinga penilaian kinerja tidak lagi obyektif. Terkadang seorang atasan tidak menyadari ingrasiasi yang dilakukan bawahan.
Seorang bawahan yang memang memiliki sifat extra role selalu nampak pada setiap waktu dan berlaku pada setiap lingkungan organisasi baik hubungan keatas, rekan setingkat maupun bawahan. Berbeda halnya dengan perilaku bawahan yang memiliki kepentingan tertentu, yang biasanya berperilaku ingrasiasi hanya pada atasan yang memiliki kewenangan penuh terhadap penghargaan ekstrinsik.

Persepsi politik organisasional berpengaruh negatif pada komitmen afektif. Temuan ini bertentangan dengan penelitian sebelumnya Drory, (1993), Randal et al. (1999), Cropanzano et al. (2000), Miller et al.. (2008). Namun, temuan ini diperkuat penelitian Witt et al.. (1998) dan Cropanzano (1997) yang menemukan hubungan positif persepsi politik organisasional pada komitmen afektif. Temuan ini juga diperkuat oleh penelitian Kacmar and Baron (1991), Witt et al. (2000) yang menemukan tidak konsistennya pengaruh persepsi politik organisasional pada komitmen afektif, walaupun secara teoritis sudah jelas bahwa persepsi politik organisasional pada komitmen afektif berhubungan terbalik. Randal et al.. (1999) menyatakan tidak kuatnya beberapa arah hubungan persepsi politik organisasional dan komitmen organisasional karena sifat dasar hubungan persepsi politik dan komitmen organisasional direfleksikan dari adanya variabel pemoderasi.

Menurut peneliti temuan ini disebabkan karena mayoritas responden dalam penelitian ini adalah karyawan yang berusia produktif antara 25 - 45 tahun (86\%). Usia merupakan variabel penting yang dapat membantu memprediksi reaksi individu pada persepsi politik organisasional. Target aktivitas politik adalah evaluasi kinerja dan promosi untuk peningkatan penghargaan ekstrinsik. Argumen ini diperkuat penelitian Ferris et al. (2002). Seringkali karyawan yang berusia lanjut digolongkan sebagai subyek negatif yang berkaitan dengan kinerja yang baik dan karyawan yang berpotensial untuk dipromosikan (Witt et al. 2004). Menurut penelitian Lashbrook (1996), mayoritas karyawan di atas usia 25 tahun diharapkan akan segera dipromosikan, sementara karyawan di atas 50 tahun tidak berharap untuk dipromosikan lagi. Hal ini berkaitan dengan perputaran karier seiring dengan bertambahnya usia, sehingga karyawan yang lebih tua cenderung memberikan perhatian lebih pada kegiatan di 
luar kegiatan pekerjaan. Karyawan yang berusia lanjut cenderung tidak berperilaku politis dan mempersepsikan politik organisasional sebagai sesuatu yang sederhana dan wajar terjadi dalam sebuah organisasi (Ferris et al. 1996). Ini artinya bahwa konteks perilaku politik dalam organisasi lebih relevan pada karyawan yang berusia produktif (Treadway et al. 2005).

Bawahan yang berusia produktif memiliki kesempatan lebih besar dalam mendapatkan alokasi sumberdaya dan penghargaan. Namun sumberdaya dalam organisasi sangat terbatas sehingga menimbulkan perilaku politik yang dipersepsikan sebagai sebuah tantangan dan cara mencapai kesuksesan karir. Pencapaian karir memiliki arti penting perusahaan bagi karyawan, sehingga karyawan terikat dengan organisasi yang akhirnya memiliki keterikatan secara emosional. Politik dalam lingkungan kerja mungkin dipersepsikan oleh karyawan berusia produktif akan berdampak pada hasil kinerja, kemudian mereka memiliki komitmen yang kuat dalam mengantisipasi tinggi persepsi politik organisasional dengan terlibat langsung pada aktivitas politik.

Ingrasiasi memoderasi pengaruh persepsi politik organisasional pada kepuasan kerja, sehingga hasil penelitian ini konsisten dengan penelitian-penelitian sebelumnya Ferris et al. (1989), Kacmar and Baron et al. (1999), Valle and Perrewe (2000), Cable and Judge (2003) serta Cook et al. (1999). Temuan efek moderasi dalam penelitian ini berupa efek moderasi yang merubah bentuk hubungan. Hal ini mengindikasikan bahwa ingrasiasi merubah pengaruh persepsi politik organisasional pada kepuasan kerja, yang artinya persepsi politik organisasional pada kepuasan kerja akan berubah menjadi positif, jika bawahan sering berperilaku ingrasiasi, dengan kata lain semakin sering karyawan ingrasiasi maka semakin tinggi kepuasan kerja. Kondisi ini berbeda dengan bawahan yang jarang ingrasiasi, pada saat persepsi politik organisasional dirasakan tinggi, maka kepuasan kerja akan semakin rendah. Tipe pemoderasian ini disebut buffer karena variabel moderasi mengurangi, bahkan merubah pengaruh negatif persepsi politik organisasional pada kepuasan kerja (Byrne, 2005).

Ingrasiasi merubah pengaruh persepsi politik organisasional pada kepuasan kerja, karena karyawan berusaha terlibat dalam lingkungan politik untuk mengurangi ambiguitas dan mencoba untuk mendapatkan kendali atas lingkungan yang tidak pasti. Kegiatan politik dinyatakan sah sebagai bentuk kontrol atau sebagai mekanisme dalam menghadapi tingginya persepsi politik organisasional yang dirasakan oleh karyawan. Ketika bawahan yang telah berhasil berperilaku politik dan memiliki andil dalam mempengaruhi atasan dalam proses pengambilan keputusan, bawahan merasakan kepuasan kerja karena harapan bawahan terpenuhi.

Ingrasiasi memoderasi pengaruh persepsi politik organiasional pada komitmen afektif. Penemuan efek moderasi dalam penelitian ini konsisten dengan penelitian sebelumnya yang dilakukan oleh Ferris et al.. (1989), Kacmar and Baron (1999), Valle and Perrewe (2000), Cable and Judge (2003) serta Cook et al. (1999). Selain itu, temuan penelitian ini menjadi menarik, karena walaupun secara statistik ingrasiasi memoderasi pengaruh persepsi politik organisasional pada komitmen afektif, namun secara konseptual temuan ini tidak memiliki arti karena hasil pengujian efek utama menunjukkan bahwa persepsi politik organisasional tidak berpengaruh pada komitmen afektif. Hal ini sejalan pernyataan Baron and Kenny, (1986) dan Podsakoff et al. (1995) yang menyatakan bahwa walaupun secara statistik efek moderasi sangat kuat, namun tidak disertai hubungan pada efek utama, maka secara konseptual efek moderasi dianggap tidak impresif. Berdasarkan hasil pengujian analisis regresi moderasian, peneliti mengindikasikan bahwa terdapat variabel lain yang di luar model yang menjadi prediktor komitmen afektif. Diduga ingrasiasi dan komitmen afektif memiliki pengaruh langsung. Argumen ini diperkuat oleh penelitian sebelumnya yang menemukan tidak konsistennya pengaruh persepsi politik organisasional pada komitmen afektif (Kacmar and Baron 1991; Witt et al.1998; Witt et al. 2004).

Selain itu, bawahan yang memiliki keyakinan tentang lingkungan politis dalam organisasinya akan mempengaruhi pola-pola kerja sepanjang rentang kariernya. Akhirnya pola-pola kerja bawahan akan diwarnai dengan aktivitas politik dilingkungan kerja, sesuai dengan nilai dan norma yang berlaku dalam organisasi. Sehingga keterikatan secara emosional bawahan dan organisasi berubah 
sesuai dengan nilai dan tujuan organisasi yaitu lingkungan organisasi yang politis. Perubahan bentuk komitmen ini merupakan suatu bentuk mekanisme dalam menghadapi tingginya persepsi politik organisasional yang dirasakan oleh karyawan (Ferris et al. 1989) dan bawahan merasa organisasi sebagai pendorong perilaku politik, karena komitmen afektif bersifat situasional seiring kondisi yang terjadi dalam lingkungan sekitarnya.

Ditambahkan, keterlibatan bawahan terhadap lingkungan politis dengan dengan menggunakan taktik ingrasiasi akan mempengaruhi penilaian atasan, bahwa bawahan memiliki komitmen afektif yang tinggi terhadap organisasi. Peran penilaian kinerja adalah sebagai tolak ukur bawahan mendapatkan penghargaan ekstrinsik dan instrinsik yang pada gilirannya bawahan merasakan kepuasan kerja. Karyawan yang memiliki kepuasan kerja akan menimbulkan komitmen afektif terhadap organisasi (Wiliam and Hazer, 1986).

\section{PENUTUP}

\section{Keterbatasan Penelitian dan Saran Bagi Penelitian Mendatang}

Pertama, pengumpulan data dalam penelitian ini hanya menggunakan satu sumber yaitu persepsi bawahan, yang memungkinkan terjadinya bias yang tinggi karena kemungkinan besar penilaian mengenai outcomes, yaitu kepuasan kerja dan komitmen afektif akan dinilai secara berlebihan. Selain itu, penilaian mengenai ingrasiasi hanya dilihat dari sisi bawahan saja tanpa memperhatikan sisi atasan sebagai seorang yang menjadi target ingrasiasi.

Peneliti telah berupaya untuk mengurangi potensi terjadinya common method bias antara lain dengan cara tidak menampilkan judul penelitian, nama variabel dan penempatan item-item yang didtribusikan secara acak pada kuesioner penelitian. Upaya-upaya tersebut dilakukan agar responden tidak mengetahui tujuan dan hipotesis penelitian.

Kedua, jumlah responden dalam setiap organisasi tidak proporsional. Hal ini diakibatkan bahwa peneliti tidak diijinkan untuk menentukan besarnya sampel dan melakukan penelitian secara langsung, namun melalui mekanisme yang berlaku dalam organisasiorganisasi tersebut sehingga peneliti tidak mampu mengendalikan jumlah, kondisi, jabatan responden yang mungkin akan mempengaruhi hasil penelitian. Sebaiknya jumlah responden dari tiap-tiap populasi dapat didistribusikan secara merata sehingga tidak ada kecenderungan latar belakang organisasi tertentu mendominasi jawaban kuesioner dengan menggunakan metode probability sampling.

Ketiga, rendahnya variansi yang dapat dijelaskan oleh variabel independen terhadap variabel dependen pada hampir pengujian hipotesis, walaupun signifikan Penelitian selanjutnya dapat menggunakan alat analisis statistik yang sama lagi untuk menguji suatu model penelitian yang hampir serupa dengan model dalam penelitian ini, hanya saja perlu dikembangkan dengan menambahkan beberapa variabel independen yang berkaitan dengan persepsi politik organisasional sehingga akan menghasilkan goodness-of- fit model yang lebih baik. Apalagi jika penambahan variabel tersebut memiliki alasan dan dukungandukungan teori yang kuat.

Keempat, pengukuran variabel komitmen organisasional hanya menggunakan dimensi komitmen afektif. Padahal komitmen organisasional dibentuk oleh tiga dimensi komitmen, yaitu afektif, normatif dan kontinuans, sehingga penelitian selanjutnya diharapkan mengukur komitmen organisasional secara menyeluruh dengan menggunakan ketiga dimensi pembentuk komitmen organisasional. Selain itu penelitian mendatang dapat melanjutkan penelitian ini dengan mengeksplor variabel yang diduga sebagai prediktor yang diidentifikasi dari hasil pengujian interaksi moderasi ingrasiasi terhadap persepsi politik organisasional pada komitmen afektif yang menjadi temuan menarik dalam penelitian ini.

\section{DAFTAR PUSTAKA}

Aguinis, H. 1995. Statistical Power With Moderated Multiple Regression In Management Research. Journal of Management, 21 (6): 1141-1158.

Ammeter, AP., C. Douglas, WL. Gardner, WA. Hochwarter and GR. Ferris. 2002. Toward a political theory of leadership, Leadership Quarterly, 13: 751-796.

Andrews, MC. and KM. Kacmar. 2001. Discriminating Among Organizational Politics, Justice, And Support. Journal 
of Organizational Behavior, 22: 347366.

Aryee, S. and YW. Chay. 1994. An Examination Of The Impact Of CareerOriented Mentoring On Work Commitment Attitudes And Career Satisfaction Among Professional And Managerial Employees. British Journal of Management, 5: 241-9

Aryee, S., YA. Debrah and YW. Chay. 1993. An Investigation Of Ingratiation As A Career Management Strategy: Evidence From Singapore. International Journal of Human Resource Management, 4: 191-212

Avolio, BJ. and BM. Bass. 1990. Transformational Leadership Development: Manual For The Multifactor Leadership Questionnaire. Palo Alto, CA: Consulting Psychologists Press.

Baron, RM. and DA. Kenny. 1986. The Moderator - Mediator Variable Distinction In Social Psychological Research: Conceptual, Strategic, And Statistical Considerations. Journal of Personality and Social Psychology, 51: 1173-1182

Baron, RA. and J. Greenberg. 1990. Behavior in Organizations: Understanding and Managing The Human Side of Work, 3 rd. New York: Allyn and Bacon.

Bartol, M., Kathryn, C. Martin and David. 1990. When Politics Pays: Factors Influencing Managerial Compensation Decisions. Personnel Psychology, 43.

Bass, BM. 1998. Transformational leadership: Industry, military and educational impact. Hillsdale, NJ: Lawrence Erlbaum.

Bass, BM. 1985. Leadership And Performance Beyond Expectations. New York: Free Press.

Bass, BM. and BJ. Avolio. 1995. The Multifactor Leadership Questionnaire. Palo Alto, CA: Mind Garden.

Burns, GM. 1978. Leadership. New York: Harper-Row.
Byrne, S., K. Zinta, CS. Jason and AW. Hochwarter. 2005. The Relationship Between Perceptions of Politics and Depressed Mood at Work: Unique Moderators Across Three Levels. Journal of Occupational Health Psychology, 10(4): 330-343.

Byrne, Zinta. 2005. Fairness Reduces The Negative Effects Of Organizational Politics On Turnover Intentions, Citizenship Behavior And Job Performance. Journal of Business and Psychology, 20 (2).

Cable, DM. and TA. Judge .2003. Manager's Upward Influence Tactics Strategies: The Role Of Manager Personality And Supervisor Leadership Style. Journal of Organizational Behavior, 24: 197214.

Carlson, DS. and PL. Perrewe. 1995. Institutionalization Of Organizational Ethics Through Transformational Leadership. Journal of Business Ethics, 14: 829839.

Carmeli, A. and A. Freud. 2004. Work Commitment, Job Satisfaction and Job Performance: An Empirical Investigation. International Journal of Organization Theory and Behavior, 7(3): 289.

Champoux, J. and W. Peters. 1987. Form, Effect Size and Power in Moderated Regression Analysis. Journal of Accupational Psychology, 60: 243-255.

Cohen, J and P. Cohen. 1983. Applied multiple regression/correlation analysis for the behavioural sciences ( $\left.2^{\text {nd }} E d.\right)$. Hillsdale, NJ: Lawrence Erlbaum and Associates.

Cook, HG., R. Ferris and JH.Dulebohn. 1999. Political Behavior As Moderators Of The Perceptions Of Organizational Politics-Work Outcomes Relationship. Journal of Organizational Behavior, 20: 1093-1105.

Cooper and Schindler. 2006. Business Research Methods. New York. Mc Graw-Hill 
Cropanzano, R., JC. Howes., AA. Grandey and P. Toth. 1997. The Relationship Of Organizational Politics And Support To Work Behaviors, Attitudes, And Stress. Journal of Organizational Behavior, 18: 159-180.

Cropanzano, RS. and KM. Kacmar. 1995. Organizational Politics, Justice, and Support: Managing The Social Climate of the Workplace. Quorum Books, Westport, CT.

Culpepper, RA. 2000. A test of Revised Scales for The Meyer And Allen. 1991. Three-Component Commitment Construct. Educational and Psychological Measurement, 60 (4): 604-616.

Damodar, Gujarati. 2003. Basic Econometrics, fourth edition. New York: McGrawHill.

Deluga, J. Ronald and J. Souza. 1991. The Effect Of Transformational And Transactional Leadership Style On The Influencing Behavior Of Subordinate Police Officers. Journal of Occupational Psychology, 64: 49-55.

Dvir, T., D. Eden., BJ. Avolio and B. Shamir. 2002. Impact Of Transformational Leadership On Follower Development And Performance: A Field Experiment. Academy of Management Journal, 45: 735-744.

Eisenberger, R., R. Huntington, S. Hutchison and D. Sowa. 1986. Perceived Organizational Support. Journal of Applied Psychology, 71: 500-507.

Ferris, GR. and KM. Kacmar. 1992. Perceptions Of Organizational Politics, Journal Of Management, 18: 93-116.

Ferris, GR. and TR. King. 1991. Politics in human resource decisions: A walk on the dark side. Organizational Dynamics, 20: 59-71.

Ferris, GR., DB. Fedor and TR. King. 1994. A Political Conceptualization Of Managerial Behavior. Human Resource Management Review, 4: 1-34

Ferris, GR., DD. Frink., MC. Galang., J. Zhou, KM. Kacmar and JL. Howard. 1996a.
Perceptions of Organizational Politics: Prediction, Stress-Related Implications, and Outcomes. Human Relations, 49: 233-266

Ferris, GR., PL. Perrewe and C. Douglas. 2002. Social Effectiveness In Organizations: Construct Validity And Research Directions. Journal of Leadership and Organizational Studies, 9: 49-63.

Ferris, GR., DD. Frink, DPS. Bhawuk and J. Zhou. 1996b. Reactions of diverse groups to politics in the workplace, Journal of Management, 22: 23-44.

Ferris, GR., GS. Russ and PM. Fandt .1989. Politics In Organizations, in Giacalone, R.A. and Rosenfeld, P. (Eds), Impression Management in the Organization, Erlbaum, Hillsdale, NJ, pp: 143-70.

Gandz, J. and VV. Murray. 1980. The Experience Of Workplace Politics. Academy of Management Journal, 23: 237-251.

Gilmore, DC. and GR. Ferris. 1989. The Effects Of Applicant Impression Management Tactics On Interviewer Judgements. Journal of management, 15: 557-564.

Greenhaus, J. 1987. Career Management. New York; The Dryden Press.

Hair, JF., WC. Black, BJ. Babin, RE. Anderson and RL. Tatham. 2006. Multivariate Data Analysis. $6^{\text {th }}$ edition. New Jersey: Pearson Education.

Harris. J. Kenneth and KM. Kacmar. 2005. Easing the strain: The Buffer Role of Supervisors in The Perceptions of politics - Strain Relationship. Journal of Occupational and Organizational Psychology, 78: 337-354.

Harrison, AW., LP. Perrewe, AW. Hochwarter and DA. Ralston. 1998. The Ingratiation Construct: An Assessment of the Validity of the Measure of Ingratiatory Behaviors in Organizational Settings (MIBOS), Journal of Applied Psychology, 83: 932-943. 
Haryati, T. 2006. Hubungan Antara Dukungan Organisasi dan Big Five Personality dengan Komitmen Organisasi. Tesis S2 PSikologi. Tidak dipublikasikan Universitas gadjah Mada, Yogyakarta

Hian, CH. and EH. Boo. 2001. The Link between Organizational Ethics and Job Satisfaction: A Study of Managers in Singapore, Journal of Business Ethics, 24: 309-324.

Higgins, CA., TA. Judge and GR. Ferris. 2003. Influence Tactics And Work Outcomes: A Meta-Analysis. Journal of Organizational Behavior, 24: 89-106.

Iverson, R.D. and DM. Buttugieg. 1998. Affective, Normativm and Continuance Commitment: Can The Right Kind of Commitmnet be Managed? Working paper, Department of Management, University of Melbourne.

Jones, EE. 1964. Ingratiation. New York: Appleton.

Kacmar, KM. and GR. Ferris. 1991. Perceptions of Organizational Politics Scale (POPS): Development and Construct Validation. Educational and Psychological Measurement, 51: 193-205.

Kacmar, KM. and M. Valle. 1997. Dimensionality of The Measure of Ingratiatory Behaviors in Organizational Settings (MIBOS) Scale. Educational and Psychological Measurement, 57: 314-328.

Kacmar, KM. and RA. Baron. 1999. Organizational Politics: The State of The Field, Links Torelated Processes, and an Agenda for Future Research, Research in Personnel and Human Resources Management, 17: 1-39.

Kacmar, KM. and DS. Carlson. 1994. Further Validation At The Perceptions of Politics Scale (POPS): A Multiple Sample Investigation, paper presented at Academy of Management meeting, Dallas, TX.

Kacmar, KM. and GR. Ferris. 1991. Perceptions of Organizational Politics Scale (POPS): Development and Construct validation, Educational and
Psychological Measurement, 51: 193205.

Kipnis, D., SM. Schmidt and I.Wilkinson. 1980. Intraorganizational Influence Tactics: Explorations in Getting One's Way. Journal of Applied Psychology, 65: 440-452.

Kumar, K. and M. Beyerlein. 1991. Construction And Validation Of An Instrument For Measuring Ingratiatory Behaviors In Organizational Settings. Journal of Applied Psychology, 76: 619-627.

Lashbrook, J. 1996. Promotion Timetables: An Exploratory Investigation Of Age Norms For Promotional Expectations And Their Association With Job WellBeing. Gerontologist, 36: 189-198.

Liden, RC. and TR. Mitchell. 1988. Ingratiatory Behaviours in Organizational Settings. Academy of management Review, 13: 578-87.

Liden, RC., SJ. Wayne and D. Stilwell. 1993. A Longitudinal Study on The Early Development of Leader-Member Exchanges. Journal of Applied Psychology, 78: 662-674.

Locke, EA. 1991. The Motivation Sequence, The Motivation and The Motivation Core. Organizational Behavior and Human Decision Processes, 50: 288299.

Lowe, KB., KG. Kroeck and N. Sivasubramaniam. 1996. Effectiveness Correlates Of Transformational And Transactional Leadership: A Meta Analytic Review Of MLQ Literature. Leadership Quarterly, 7: 385-425.

Luthans, F. 1995. Organization Behavior, McGraw Hill Inc, USA

Meyer, JP., NJ. Allen and CA. Smith. 1993. Commitment To Organizations and Occupations: Extension And Test Of A Three-Component Conceptualization. Journal of Applied Psychology, 78: 538-551.

Meyer, JP., DJ. Stanley, L. Herscovitch and L. Topolnytsky. 2002. Affective, Continu- 
ance And Normative Commitment To The Organization: A Meta-Analysis of Antecedents, Correlates, And Consequences. Journal of Vocational Behavior, 61: 20-52.

Miller, K., MA. Rutherford and RW. Kolodinsky. 2008. Perceptions Of Organizational Politics: A MetaAnalysis Of Outcomes. Journal Business Psychology, 22: 209-222.

Mintzberg, H. 1983. Structure in fives: Designing effective organizations. Englewood Cliffs, NJ: Prentice-Hall.

Noe, RA. and J. Hollenbeck. 2000. Human Resource Management: Gainning Competitive Advantage, $3^{\text {rd }}$ ed. New York; McGraw-Hill Companies, Inc.

Pillai, RA., CA. Schriesheim and ES. Williams. 1999. Fairness Perceptions And Trust As Mediators For Transformational And Transactional Leadership: A TwoSample Study. Journal of Management, 25: 897-933.

Podsakoff, PM., SB. Mackenzie and WH. Bommer. 1996. Transformational Leader Behaviors And Substitutes For Leadership As Determinants Of Employee Satisfaction, Commitment Trust, And Organizational Citizenship Behaviors. Journal of Management, 22: 259-298.

Podsakoff, PM., SB. MacKenzie, M. Ahearne and WH. Bommer. 1995. Searching For A Neddle In Haystack: Trying To Identify The Illusive Moderators Of Leadership Behaviors. Journal of Management, 21 (3): 422-470.

Prajogo, W. 2008. Pengaruh Kepemimpinan dan Kepribadian pada Modal Sosial serta Dampaknya pada Kinerja. Disertasi. Tidak dipublikasikan Universitas gadjah Mada, Yogyakarta.

Randall, ML., R. Cropanzano, CA. Bormann and A. Birjulin. 1999. Organizational Politics And Organizational Support As Predictors Of Work Attitudes, Job Performance, And Organizational Citizenship Behavior. Journal of Organizational Behavior, 20: 159-174.
Schriesheim, CA. and TR. Hinkin. 1990. Influence Tactics Used By Subordinates: A Theoretical And Empirical Analysis And Refinement Of The Kiphis, Schmidt, And Wilkinson Subscales. Journal of Applied Psychology, 75: 246-257.

Spector, PE., PT. Van Katwyk, MT. Brannick and PY. Chen. 1997. When Two Factors Don't Reflect Two Constructs: How Item Characteristics Can Produce Artifactual Factors. Journal of Management, 23: 659-678.

Valle, M. and PL. Perrewe. 2000. Do Politics Perceptions Relate To Political Behaviors? Tests Of An Implicit Assumption And Expanded Model, Human Relations, Vol. 53: 359-86.

Vigoda, E. 2000. Organizational Politics, Job Attitudes, And Work Outcomes: Exploration And Implications For The Public Sector. Journal of Vocational Behavior, 57: 326-47.

Vigoda, E. 2002. Stress-Related Aftermaths To Workplace Politics: The Relationships Among Politics, Job Distress And Aggressive Behavior In Organizations, Journal of Organizational Behavior, 23: 571-91.

Vigoda, E. 2007. Leadership Style, Organizational Politics, And Employee's Performance. Personnel Review, 36 (5): 661-683

Vredenburgh, DJ. and JG. Maurer. 1984. A process Framework of Organizational Politics. Human Relations, 37: 47-66

Wayne, SJ. and GR. Ferris. 1990. Influence Tactics, Affect, And Exchange Quality In Supervisor-Subordinate Interactions: A Laboratory Experiment And Field Study. Journal Of Applied Psychology, 75: 487-499.

Wayne, SJ., RC. Liden., IK. Graf and GR Ferris. 1997. The Role Of Upward Influence Tactics In Human Resource Decisions. Personnel Psychology, 50: 979-1006. 
Williams, LJ. and JT. Hazer. 1986. Antecedents And Consequences Of Satisfaction And Commitment In Turnover Models: A Reanalysis Using Latent Variable Structural Equation Methods', Journal of Applied Psychology, 71 (2): 219231.

Wilson, AP. 1995. The Effects Of Politics And Power On The Organizational Commitment Of Federal Executives. Journal of Management, 21 (1): 101-118.

Witt, LA., MC. Andrews and KM. Kacmar. 2000. The Role Of Participative Decision Making In The Organizational Politics-Job Satisfaction Relationship. Human Relations, 53: 341357.

Witt, LA., DC. Treadway and GR. Ferris. 2004. The Role Of Age In Reactions To
Organizational Politics Perceptions. Organizational Analysis, 12 (1): 39-52.

Witt, LA., KM. Kacmar, DS. Carlson and S. Zivnuska. 2002. Interactive Effect Of Pesonality And Organizational Politics On Contextual Performance, Journal of Organizational Behavior, 23: 911-26.

Yukl, G. 1994. Leadership in Organizations (3rd ed.). Englewood Cliffs, NJ: Prentice-Hall.

Zaleznik, A. 1992. Managers and leaders: Are they different? Harvard Business Review, 7: 126-136.

Zivnuska, S., KM. Kacmar., LA. Witt, DS. Carlson and KV. Bratton. 2004. Interactive Effects of Impression Management and Organizational Politics on Job Performance. Journal of Organizational Behavior, 25: 627-640. 